\title{
Korean Suicide Protest as Anomic Response to Labour Disempowerment
}

\author{
Minsun Ji, University of Colorado Denver, United States of America
}

\begin{abstract}
The article argues that the growth of worker protest suicide in the 2000s in South Korea is related to current neo-liberal political-economic conditions in Korea, including: 1) the growing crisis facing increasingly irregular and part-time workers, and 2) the construction of an anti-labour legal regime giving Korean workers few legal options for collective engagement in workplace actions. Legal obstacles facing labour activists include both business and state actors increasingly using compensation lawsuits and provisional seizure tactics to seize the assets of unions and striking workers. As the Korean labour movement finds itself increasingly marginalised by the crippling anti-labour legal innovations of the last two decades, labour resistance has increasingly manifested in extreme forms of individualistic protests, such as worker suicide. Though products of anomic despair, these suicides retain the capacity to inspire collective labour action and to leverage change.
\end{abstract}

\section{KEYWORDS}

labour movement; protest suicide; provisional seizure; neo-liberalism; Korea

\section{Introduction}

Bae Dal-ho, a labour leader at Korea's Doosan Heavy Metal company, committed suicide in 2003. He was previously imprisoned for an illegal strike, and upon release from prison half of his salary, his retirement savings and his house were seized by the company he had struck against (Jang, 2004a, 2004b). Bae had become a victim of Korea's provisional seizure law which allows companies to seize the income and assets of employees who engage in strikes and other illegal labour actions against the company, while courts are considering the labour case. He committed suicide two days before his meagre monthly payday, leaving the following note:

I was not paid for more than six months, but there is no money that I can receive... It is too much to take it. Eighteen people were fired, ninety workers were laid off, and I am afraid that we will not sustain and endure these harsh punishments of provisional seizure, wage garnishment, anti-labor policy... But, comrades, please fight until the end, and I hope you win. I hope that all laid-off workers can return to work. I will always be watching you at our Democracy Plaza (Korea Joongang Daily, 16 January 2003).

Bae's reminder that "I will always be watching you at our Democracy Plaza" and his appeal to comrades to "fight until the end" speak to the political meaning of his suicide. In Korea, protest suicide by workers has a long tradition, dating in the modern era to the self-immolation of garmentworker Chun Tae-Il, whose 1970 dying plea to remember the labour law helped provoke decades of labour resistance, culminating in the Great Workers' Struggle of 1987. 
There are many worker suicides in Korea. Self-immolations are the fourth highest in the world and at least 133 workers committed labour-action-related suicide between 1980 and 2012 (Biggs, 2005; Lim, 2018). Worker suicide has traditionally been regarded as a noble act of self-sacrifice across Korean society, and many suiciding workers have been regarded as yeolsa (martyrs), who demonstrated strong will through dying acts of resistance for the sake of co-workers and the cause (Lim, 2018; S-C. Kim, 2019). But this traditional notion of the suiciding worker as yeolsa has shifted over time. Before democracy unfolded in Korea in the 1970s and 1980s, many workers died as revered martyrs while calling for Korea's democracy, but the repertoire of worker protest suicide since democratisation is increasingly not evoking the same level of perceived martyrdom in today's era of neo-liberal economics. Lim (2018) posits that the period after the 1997 Korean economic crisis (and subsequent neo-liberal economic reforms) is a period of "dismantlement of martyrs" as worker deaths since the late 1990s have not galvanised the public nor have they played a role in transforming labour politics in Korea. Although the number of Korean worker suicides has continued to be quite sizable in the 2000s, in protest of anti-labour policy and workplace conditions, the effectiveness of worker suicide in mobilising the public and changing workplace conditions has weakened.

By utilising the high-profile case of thirty worker suicides that occurred at the SsangYong automobile company between 2009 and 2018, this article examines why worker suicide in Korea has shifted from movement-oriented repertories of "righteous actions" by martyrs to anomic suicides of individualised desperation, less connected to broader labour movements. The article argues that two conditions of neo-liberal economic restructuring have contributed to this shift: 1) the crisis facing increasingly irregular and part-time workers in Korea; and 2) Korea's militant labour movement culture, which is deeply committed to mobilisation against worker exploitation, and which builds on a tradition of yeolsa worker suicides, but which has increasingly narrow options available for collective engagement in workplace actions. As the Korean labour movement finds itself increasingly marginalised by crippling anti-labour legal innovations of the last two decades (such as Korea's increasing use of compensation lawsuits and provisional seizure tactics against striking workers), labour resistance has increasingly manifested in extreme forms of individualistic protest, such as worker suicide, which are ever more disconnected from the broader social movement. Though suicides are increasingly individualised, this article also shows that these anomic suicides of despair retain their capacity for evoking cycles of collective labour activism and workplace change in Korea.

\section{Suicides of Purpose: Korea's Tradition of Yeolsa Labour Martyrs}

Korean worker suicide as a political strategy to mobilise the public has a long history and can be considered a kind of "collective action" by workers because it is often used to advance "the cause of their movement" (H-J. Kim, 2008: 572-3). Drawing on the honoured conception of yeolsa - a person who sacrifices their life without violent resistance in the name of an important social cause - many suiciding workers in past decades have been seen as part of a broader campaign of resistance to unfair labour exploitation. The well- known suicide of Chun Tae-il is a case in point.

A low-wage garment worker, Chun Tae-il immolated himself on 13 November 1970 on the streets of Seoul in protest against worker exploitation. Chun Tae-il was a labour leader desperate to improve working conditions; he demanded the enforcement of labour laws for 20000 to 30000 low-wage "Peace Market" workers who made clothes without minimum wage or other basic rights. When Chun's numerous appeals to the labour department to improve working conditions at the 
Peace Market were ignored, he doused himself with kerosene and set himself on fire. In his diary, Chun described the social meaning behind his suicide: "I come to an absolute decision to be alongside my poor brothers and sisters. I will throw myself away. I will die for you so as not to leave you... I am struggling to be the dew for countless withering innocent lives (Y-R. Choi, 2003: 28). His dying plea, much repeated among labour activists to this day, was that "the laborer is also a human being... Honor the labor law... Do not exploit workers... Don't let my death be for nothing" (Korea Joongang Daily, 16 January 2003).

Chun Tae-il concluded that there was no room for meaningful labour organising in Korea's closed authoritarian system at the time, and that only a public, suicidal martyrdom might water the fields of change. Chun's protest suicide shocked and mobilised thousands of workers and university students into subsequent collective actions, and "marked the transition in the labor movement from the more experimental and cooperative labor politics of the 1960s to a confrontational politics of the 1970s" (Nam, 2013: 880). In the decades to follow, an increasingly militant labour movement took to the streets, together with student activists, culminating in the great democratic upheaval of 1987.

Since Chun's self-immolation, the act of worker suicide has typically not been seen by Koreans as an isolated act of a desperate and ill individual, but as "an action of strong resistance by brave people against injustice" (Jang, 2004a: 271). A vital legacy of Chun Tae-il is that workers who commit suicide calling for improved social conditions are commonly regarded as martyrs, utilising a well-recognised strategy to "confront oppression, felt injustice and social suffering" (Cheikh, Rousseau and Mekki-Berrada, 2011: 495).

This kind of martyrdom is exalted through the force and memory of the minjung - a Korean concept of the "the people" or "the masses" as a living, breathing force. In Korean thought, the minjung is "all those who are politically oppressed, socially alienated, and economically excluded from the benefits of economic growth" (Koo, 1999: 59). This concept of the populist minjung came to define the oppositional political culture of marginalised Koreans that emerged in the late 1970s and 1980s when broad segments of Korean society (most notably labour activists and university students) took to the streets in an ultimately successful revolt against the military regime (N. Lee, 2007).

The concept of minjung as an oppressed but potentially liberating populist force was an effective radicalising notion in Korea's recent struggle for democracy. Following the martyrdom of Chun, references to the suddenly awakened minjung emerged as "a dominant form of discourse, a slogan and strategic tool for uniting and mobilizing diverse political and social struggles in the 1980s" (N. Lee, 2007: 59). Notions of minjung egalitarianism, awakened by the sacrifice of Chun Tae-il, shaped the labour movement as many intellectuals in the 1970s and 1980s entered factories to become workers themselves and moved to low-income communities to live alongside low-wage workers, helping them to organise labour unions. Students worked in solidarity with labourers, organising unions, neighbourhood celebrations, political night schools, and politicised art festivals.

In this light, worker suicide was typically understood as part of the minjung movement in Korea in the 1970s and 1980s. It was seen as an effort to release a deeply felt grief (Han), as well as to transform one's individualistic suffering into collective liberation of the people through selfsacrifice (Doucette, 2013). This notion of self-sacrifice was often imbued with a kind of utopian idealism which emphasised that worker self-sacrifice through suicide was a meaningful moral force, representing the collective suffering of the people, the moral dignity of the unbending worker, and the will of history (B-C. Park, 1994). In this framework, protest suicide has often been used as a "final solution, not only to challenge the government morally but also to shake up the public consciousness in an attempt to empower the weak" (B-C. Park, 1994: 77). 
In previous decades, suiciding workers themselves typically saw their actions in this socially meaningful way. Between the 1970s and 1990s, over 135 workers committed suicide, calling for democracy and workers' rights under the authoritarian regime (Lim, 2018). Their last statements and wills showed that many of these workers hoped that their sacrifice would overcome political obstacles and give encouragement for the public to fight for social change. However, as the minjung movement waned in the 2000s, and powerful new forms of labour repression emerged, the repertoire of worker suicide as self-sacrifice and dedication to the life of the oppressed has arguably lost some of its meaning - a more isolated and anomic form of worker suicide seems to be replacing the yeolsa tradition of old. Before these more recent worker suicides and their meaning can be examined in detail, however, some attention to the broader political-economic environment facing Korean labour in the 2000 s is necessary.

\section{Building a "Democracy Without Workers": Demobilising Korea's Militant Labour}

Though social movement militancy, fuelled partly by yeolsa of the 1970s to 1990s, brought political democracy to Korea, Kang (2018) calls today's Korea a “democracy without workers" because of the continued (and even increasing) repressive control of labour activism by Korea's elites (also see Song, 2013). Korea's current "democracy without workers" has two important structural characteristics: 1) an increasingly neo-liberalised economy, with expanded openness to foreign capital and increased flexibility of the labour force in the form of declining job security, lower wages and the growing use of contingent workers; 2) the intensifying marginalisation of organised labour from full participation in civic life, even after post-1987 democratisation reforms. Korea's neo-liberal economic order is deeply connected to the enduring power of the "chaebol-state complex", in which tight alliances between political and chaebol (corporate) elites dominate civic life, and legal rules tightly constrain the opportunities for organised labour to advance its interests (J-J. Choi, 2010; Doucette and Kang, 2018; Kang; 2018;). This profoundly worker-hostile legal environment is part of a political reality in which democratisation dynamics have waned since the 1987 upheaval, and economic elites have led a neo-liberalisation process that has exacerbated social polarisation while building a legal regime that substantially marginalises labour interests.

Civilian presidents elected after democratisation in 1987 have supported the unfolding of neoliberal anti-labour policies through the 1990s and the 2000s. The first civilian president, Kim Young-sam (1993-1997), advanced neo-liberal economic policies such as a more flexible labour market and opening Korean financial and capital markets to foreign investors. The second civilian president, Kim Dae-jung (1997-2002), continued similar anti-labour policies in response to pressure from the global community to adopt a range of neo-liberal economic policies following the 1997 economic crisis. In exchange for a record-setting bailout of $\$ 58.4$ billion, Kim accepted the neo-liberal restructuring agenda of the International Monetary Fund (IMF), which offered emergency loans conditional on Korea reforming its economy in a way that maximised the freedom of global capital to engage a flexible, part-time and often poorly paid workforce (B-H Lee, 2015: 210). It is revealing that although the IMF imposed these neo-liberal labour reforms as a condition of the 1997 bailout package, it was Korean government officials themselves who "asked the IMF to include anti-labour measures in the reform package attached to the rescue loans" (Song, 2013: 54). Korean leaders believed that the unions should be pressured to share the "burdens of pain of economic restructuring" by accepting wage reductions, mass layoffs, and trimming of pensions and other benefits (Koo, 2001: 245). 
While the neo-liberalised Korean economy has exposed workers to increased pressures of a polarised and globalised economic order, organized labour in Korea has never been fully incorporated into the increasingly democratic Korean civil society and is unable to adequately protect its interests in this new order (J-J. Choi 2010). Legal challenges include: restrictions on the right of broad sectors of workers (such as civil servants and teachers) to unionise or strike; a ban on "third party intervention" in labour disputes (for example, through solidarity strikes); the endurance of trade union "monopoly" unions sponsored by business management itself; severe criminal and civil penalties facing organisations and individuals who engage in labour actions not deemed justifiable by courts under Korea's exceptionally pro-business labour laws; and frequent mobilisation of overwhelming police force against labour actions (KCTU, 2009; ITUC, 2012; Doucette and Kang, 2018).

Article 33 of the Korean Constitution and Article 3 of the Trade Union and Labor Relations Adjustment Act of 1997 (TULRAA) both recognise the right of workers and unions to engage in labour organising and collective actions such as strikes. Though these laws establish fundamental labour rights in Korea, dominant business interests have found creative strategies of legal labour repression. A telling example of the hostile legal environment increasingly facing Korean labour is the common use of compensation lawsuits and provisional seizure actions by companies and local police forces to attack labour union activities, regardless of formal legal protections.

In 2011, the Korea semiconductor company SEC published A Roadmap to Workeforce Restructuring, which included plans to undermine the company union through the strategic use of "provisional seizures" of union members' personal assets (Sun, 2019). Provisional seizure actions against unions and labour activists exploit the fact that although Korean law allows for union association and collective labour action (and protects workers from damage suits for their activism), the law also narrowly limits these labour rights to what are termed "justifiable" labour actions. Article 1 and Article 4 of the TULRAA limit the "justifiable activities" of labour unions to what are defined as "legal" strikes. The act illegalises all "non-justifiable" labour actions and authorises both criminal and civil penalties against organisations or individuals engaged in these actions. Under this law, legal strikes can only be called in response to specific workplace conditions (such as bargaining for increased wages or protesting non-compliance with a collective bargaining agreement).

Strikes are defined as unjustifiable and illegal if they are called in response to normal managerial decisions (such as layoff decisions, workplace restructuring actions, off-shoring or outsourcing, or bankruptcy filings). Strikes are also illegal if they are third-party sympathy strikes, if they involve important public services (such as rail transit), or if they are called in response to general government policy (such as cuts in social services, privatisation plans, pension cuts or new free trade policies), rather than directed at a specific business's actions. Strikes are also illegal if they are called by irregular, ${ }^{1}$ non-unionised workers, if they are wildcat strikes of local union chapters without parent union approval, or if they are called before an employer has had adequate time to consider a collective bargaining proposal (Jang, 2004a; Doucette and Kang, 2018).

This legal regime means that most strikes and labour actions in Korea are found by authorities to be illegal, and thus Cho (2015: 7) considers "the current labour law as a police law for labour control rather than as labour law in a genuine sense". Because labour actions are mostly illegal, any worker engaging in a strike can be found guilty of "obstruction of business" under Article 314 of

${ }^{1}$ Irregular workers are associated with part-time work, contingent work, seasonal work, self-employment, on-call work, independent contractor status and domestic labour. Often, they do not enjoy the full benefit of a nation's labour laws or a company's work policies. 
the Korean criminal code. Beyond criminal charges, workers can also face civil penalties (such as seizures of their income and assets) for "illegal" labour actions that undermine the profits of the business and provoke state policing expenses. Workers can be sued during a strike for simply not showing up to work, which is a civil offense of "refusing to provide labor" (Cho, 2015: 7). Moreover, companies suing for such civil claims can pursue a "provisional seizure" of worker assets even before the case is decided, putting "union funds and worker salaries under temporary attachment while they wait for final court rulings about the legality of labor actions" (HartLandsberg, Westra and Jeong, 2007: 210-11; see also Jang, 2004a, 2004b). In addition to companies suing unions and individual workers for damages, government entities such as the police can also pursue compensation suits, charging unions for policing costs during labour actions, such as the cost of helicopter tear gas attacks, and for alleged damage to police cars, weapons and equipment (ITUC, 2016). The provisional seizure of worker assets under these laws typically lasts "until the court makes a final decision about the companies' compensation suit against the labor union and individual laborers" (Jang, 2004a: 272). Thus, companies in Korea frequently garnish a substantial portion of an employee's earnings in order to recover damages for loses caused by "illegal" strikes - with such seizures being allowed "provisionally", even before a strike is over or the courts have ruled on its legality (Cook, 2003). This provisional seizure of assets can last for years.

In this way, Korea's narrow definition of lawful labour actions allows for the "frequent targeted dismissal of certain union officials/members or retaliatory lawsuits, resulting in astronomical damages and provisional seizure of property" (Cho, 2015: 6). Seizing the assets of labour organisations and individual workers, and threatening them with massive compensation suits, have become a clever tool of Korean businesses, leading to "containment and erosion of workers' freedom of association by preventing collective bargaining and muzzling of union campaigns" (Doucette and Kang, 2018: 2).

Provisional seizure and compensation suits were first used in 1989, when the court ordered the Unity Heavy Industry union to pay its company $\$ 81000$ for damages that the company suffered as a result of a labour strike (E-J. Kim, 2014). Although provisional seizure was rare from 1989 to 2002, the number of seizures rapidly expanded during the Roh Moo-hyun presidency (2003-2008) as labour conflicts between unions and companies increased due to economic restructuring processes which resulted in the rapid growth of irregular workers. The number of what the state called "illegal strikes" was much higher than in earlier years (S-G. Lee, 2004), and President Roh encouraged companies and police forces to utilise civil courts and the provisional seizure law to undermine labour actions without involving mass arrests (Jang, 2004a).

As a result, the total amount demanded in provisional seizures in June 2002 was 119 billion won (US $\$ 99.2$ million) for thirty-eight companies, while total provisional seizures increased to 205.6 billion won (US\$177.3 million) for fifty companies by January 2003 (Jang, 2004a). Through the end of the decade, Korean companies made claims upon US\$50 million to $\$ 100$ million of union and worker assets every year through such provisional seizure actions (KCTU, 2009; Doucette, 2013, Song, 2013, E-J. Kim, 2014). Overall compensation claims by companies against labour activists increased 500 per cent between 2002 and 2017 (Sun, 2019). In 2014, a survey of the Korean Confederation of Trade Unions (KCTU) found that compensation lawsuits were averaging US $\$ 9$ million per workplace that sued, an increase from the average claim of $\$ 1$ million in damages per workplace in 2003 (Kwon, 2015). In a notable case, President Lee Myung-bak (2007-2012) used multi-million-dollar provisional seizure actions against union members to break the Korean Rail Strike of 2009 (called in response to rail privatisation efforts) (E-J. Kim, 2014). In 2011, a compensation suit by Hyundai claimed millions in damages from striking workers, and the company began to deduct $\$ 210$ in monthly wages from workers who were forced to work longer 
hours than stipulated in their employment contract due to the need to pay compensation claims (ITUC, 2012; E-J. Kim, 2014).

The same kinds of anti-labour policies continued under the presidency of Park Geun-hye (2013-2017). Park pushed for reforms to make it easier for companies to shorten work hours, outsource labour, and base wages more on individual merit rather than on seniority or union contracts. New reforms allowed a company to hire a part-time worker for up to four years without offering a full-time contract or benefits, allowed employers to change employment conditions at will and without consulting unions, and eliminated the rule that required employers to pay severance of at least thirty days' wages for each year of service when a long-term employee was dismissed (Lee and Elich, 2015). In tandem with these anti-labour reforms, the total amount of provisional seizure and compensation suits reached its highest point during the presidency of Park Geun-hye. According to the KCTU, as of June 2017 there were sixty-five provisional seizure cases against twenty-four different labour unions, adding up to total claims of $\$ 186.7$ million dollars against Korean unions (Oak, 2017; R-G. Park, 2017).

Though such "soft" civil actions do not capture the attention of global labour activists or Korean citizens in the same way as do mass arrests, beatings and water canon deployments, they are devastating tools of oppression, meant to break the back of Korean organised labour. When unions and workers face incredibly high compensation claims, the only path commonly given out of the dilemma is to give up on union activity. One worker described how her eighty-seven coworkers waged a strike in 2010 against an electronics company that was not paying the wages specified in the collective bargaining agreement. The company responded by suing workers for US $\$ 26.89$ million in damages. "The company used the damages lawsuit as a form of blackmail", the worker testified. "They said we would never be able to pay back 30 billion won and offered to waive our liability if we would quit the company" (Y-K. Lee, 2019).

In another example, Hyundai dropped its asset seizure case against 135 members of the Ulsan Irregular Workers union after 134 of them withdrew from the union and dropped their demands for regularisation (Kwon, 2015). In the SsangYong Motor strike of 2009, discussed in detail below, compensation suits were dropped against workers who agreed to leave the strike lines, but many of those workers were subsequently compelled to participate in management-staged counterprotests against the union, for fear of facing another round of company lawsuits. These examples demonstrate that "when the employers sue for the provisional seizure of assets of trade unions or its individual members or their surety, they don't have any other purpose but labour control, or, furthermore, incapacitation and collapse of the trade unions" (Kwon, 2015: 8).

The frequent use of civil claims as a response to union strikes is highly unusual in that no other countries in the Organisation for Economic Cooperation and Development (OECD) regularly use provisional seizures to penalise individual union members for labour actions $(\mathrm{S}-\mathrm{H}$. Lee, 2006; Doucette and Kang, 2018). Over one hundred years ago, France prevented employers from seeking compensation from striking labour union members. In Japan, seeking provisional seizures is legitimate, but there has been no provisional seizure case for decades (Doucette and Kang, 2018). However, in Korea, these kinds of actions indicate the profound narrowing of institutional mechanisms for incorporating labour's concerns into broader society. While post-1987 democratisation opened opportunities for civil society institutions to grow, labour unions have never been fully included as political actors. It has not mattered whether "the government in power was authoritarian or democratic, conservative or progressive", as organised labour has always been under attack in the neo-liberal economy (J-J. Choi, 2010: 10).

One consequence of this profoundly labour-hostile "democracy without workers" is that some workers have continued the Korean tradition of suicide in response to workplace exploitation. 
But increasingly, many of these suicides occur in isolated, individualistic form, disconnected from broader labour actions. Some observers have concluded that these anomic suicides do not have the politically transformative potential of old. Still, there is evidence of the old yeolsa spirit, capable of igniting fire in the minjung, even in these recent, more anomic suicides. The case of SsangYong Motors provides a case in point.

\section{The SsangYong Labour Struggle as Neo-liberal Exemplar}

SsangYong Motors was a major Korean automaker that merged with Daewoo Motors following the financial crisis of 1997 and was subsequently bought in 2004 by a Chinese auto company, Shanghai Motors (Y-K. Lee, 2015). At the time of the takeover, SsangYong had 8700 employees, but the Chinese owners proceeded to transfer SsangYong production technology to facilities in China, while scaling down manufacturing in Korea. Following the global economic crisis of 2008 and years of technology transfers from Korean to Chinese facilities, SsangYong filed for bankruptcy in 2009. After SsangYong went through a bankruptcy restructuring process, the company was bought in 2011 by Mahindra \& Mahindra Limited, an Indian-owned multinational automobile company (HT Correspondent, 2011).

As part of the bankruptcy proceedings, SsangYong managers proposed layoffs without warning for 43 per cent of all factory workers (2 646 workers), who had averaged more than fifteen years of employment (Park and Rho, 2015). When the news of layoffs was announced, one irregular SsangYong worker took his life in protest, and another died of a stress-induced cerebral haemorrhage the next day (M-J. Kim, 2015). SsangYong's restructuring of jobs, involving layoffs of thousands of workers at short notice, shows that Korea's economy in the last twenty years has adopted increasingly neo-liberal characteristics, including the rapid restructuring of jobs as well as increased numbers of irregular workers. Though the SsangYong chapter of the Korean Metal Workers Union (KMWU) proposed reducing shift times and wages for all factory workers and offered the workers' pension fund as collateral for new bank loans to the company, SsangYong management rejected these offers and moved forward with mass layoffs of thousands of workers. Company executives also faced pressure by Korea's industrial banks who made massive layoffs of workers and permanent wage reductions a condition for the company to receive additional loans (up to US $\$ 400$ million) (Heo, 2014).

The purchase of SsangYong by Shanghai Motors also represented neo-liberal dynamics, as this purchase subjected SsangYong workers to the demands of global industrial markets and financial flows with little connection to local places or workers. The motivation for Shanghai's purchase of SsangYong was to facilitate the transfer of technological knowledge to manufacturing facilities in China, rather than making a profit from automobile manufacturing in Korea. To facilitate this technology transfer and hollowing out of SsangYong's Korean facilities, the company went through an abrupt restructuring, which included massive layoffs and replacing full-time workers with contingent and part-time workers. Subsequently, when Shanghai Motor filed for bankruptcy, another global actor (Mahindra \& Mahindra) purchased SsangYong in 2011. When the coronavirus hit in 2020, a global sales plunge of Mahindra's own vehicles in India led the company to cancel all plans to further invest in SsangYong facilities and exposed workers to a new round of economic risk (Vijayenthiran, 2020).

When SsangYong workers decided to go on strike in protest against massive layoffs in 2009, workers received a demand from company officials to leave the union if they wanted to come back to work. One pregnant worker miscarried and committed suicide shortly thereafter. SsangYong 
managers organised aggressive action against the union, including ordering workers to participate in management-staged counter-protests against the union if they wanted to keep their jobs. After seventy-seven days, the SsangYong strike was broken after the company hired a private helicopter to spray liquid tear gas all over the factory, and then sent 2000 private security forces to storm the facility and beat workers. This assault was followed by police storming the factory, firing rubber bullets, deploying water cannons, beating workers and conducting mass arrests (Y-J. Lee, 2017).

With the strike broken, no dismissed workers regained their jobs. Most could not find work elsewhere, due to industry-wide blackballing of union activists by the SsangYong company. Sixtyfour worker leaders were jailed, including Han Sang Gyun, the eleventh president of the KCTU (2015-2017), who was jailed for three years for leading the strike. Adding insult to injury, both SsangYong and local police proceeded to sue workers who had participated in the strike for civil damages. In considering the request for seizure of assets as part of the company's compensation suit against the workers, the Korean Supreme Court held that the decision to lay off workers was a managerial decision, and that strikes against such managerial decisions were illegal. As a result of that ruling, the union and its members were liable for all economic damage caused to SsangYong as a result of their labour actions - and also liable for policing costs associated with repressing their illegal strike. The court determined that 7.6 billion won (US $\$ 6.6$ million) was owed by union organisations and activists for their SsangYong strike, with another 20 per cent of this amount added annually in delay of payment charges while the case was under appeal. In addition, police successfully sued striking workers for damage to a helicopter and industrial equipment caused during police actions against the unionists, and the Korean court ordered workers to pay another 1.17 billion won (US\$2.16 million) in 2015, in addition to interest charges which accrued as the case was on appeal (Yi, 2019). A 2019 survey found that 173 workers out of 233 (74.2 per cent) had faced these economic penalties from SsangYong due to their "obstruction of business", including "damages caused by a labor strike" (J-Y. Park, 2019: 13).

\section{Anomic Suicide in Neo-liberal Times}

Between 2009 and 2011, there were thirteen suicides of workers and family members related to the SsangYong labour action. The first suicide occurred in July 2009, as a worker who left the company when SsangYong threatened layoffs could not endure the economic difficulty associated with not finding replacement work. In another case, the wife of a labour union leader, Lim Moochang, jumped from her apartment in despair at their family's economic situation. Her husband committed suicide one year later, marking the thirteenth worker suicide (C-G. Lee, 2011).

The economic desperation among these suiciding workers is shown in their final statements. "Due to the restructuring of the company, my salary was reduced dramatically, and it is painful to feed my kids ramen [instant noodles], because I can't afford to buy rice", wrote one worker; "Living like this is miserable and painful." Another wrote, "I only made you suffer, and I am leaving you debts only until the last moment. I am so sorry" (Heo, 2014). Validating this lamentation, a professional survey of SsangYong unionists early on in the labour action found that 82 per cent had personal debt increase substantially during the strike, and about 50 per cent of workers experienced threats from the company that they would be personally sued for damages if they did not leave the strike lines (KCTU, 2009).

The situation did not improve with the breaking of the strike after seventy-seven days. After the strike ended, previously striking workers now had no jobs, little potential for new regular employment due to company blackballing, and lived in fear of asset seizure. Most SsangYong 
workers ended up working as irregular day laborers; workers' average post-restructuring monthly income of 822,800 won (\$757) was 75 per cent less than their previous salary. A psychiatrist examined these union members and found that 94 per cent suffered from post-traumatic stress disease (PTSD). A union survey of SsangYong's laid-off workers showed that 85 per cent reported serious depression. Another survey of dismissed workers in 2019 reported that 31 per cent of men who were subject to compensation suits for allegedly causing economic harm to SsangYong thought of committing suicide. This rate is 19 per cent higher than rates of suicidal ideation by all Korean men (J-Y. Park, 2019).

As the dozens of despairing suicides at SsangYong Motor company since 2009 reveal, one consequence of the neo-liberal shift from regular employment to irregular and contingent work, amid the marginalisation of organised labour from full civic participation, has been increased suicidal ideation among Korean workers (W. Kim et al., 2019). S-C. Kim (2019) has documented that the number of worker suicides between 1997 and 2005 was higher than in the previous decade and argues that increased worker suicide is the result of new forms of "punitive anti-labour tactics adopted by the government and business, such as economic damage lawsuits and provisional seizures. Workers facing an increasingly ruthless labour market have been driven to suicides of frustration, despair and helplessness".

Many of the recent worker suicides are not as typically linked to notions of martyrdom and collective action campaigns as suicides in previous decades, either in the internal understanding of the worker or in the external broader social impact of the event. Émile Durkheim coined the term "anomic suicide" to refer to a situation in which a person's suicide results from personal, psychological disequilibrium, unconnected to broader causes (Durkheim, 2002 [1897]: 219). He felt this kind of anomic suicide occurred as a result of the suffering caused by advanced industrialism, where people feel "unstable equilibrium" in their lives and are unable to connect to deeply felt social norms to give meaning to their actions (Durkheim, 2002 [1897]: 223).

Using this framework, Waters (2015) argues that many recent worker suicides in Korea are an anomic product of neo-liberal economic restructuring which has increasingly isolated workers from one another. Workers' final statements to their families support this characterisation as most did not include any broader call to action and rather expressed guilt toward their families. Most suiciding workers left final statements meant only to "convey a message to specific individuals" but not to "society in general" (Waters, 2015: 503). H-J. Kim (2008) similarly argues that social anomie - a feeling of withdrawal and loneliness - increasingly characterises recent worker suicides, rather than older notions of yeolsa who used suicide as a "form of collective action" (H-J. Kim, 2008: 572). Both H-J. Kim (2008) and Waters (2015) see the changing nature of Korean worker suicide as driven by political and economic developments since the late 1980s - specifically, the emergence of a neo-liberal "democracy without workers" that has eroded older forms of Korean labour solidarity and led increasing numbers of workers to face lonely, anomic suicide rather than yeolsa suicides of purpose, pointing the way to an even more determined labour struggle.

Part of the reason that individual worker suicide is increasingly disconnected from the broader labour movement is that the Korean labour movement itself is increasingly fractured. Korean union density fell to 12.4 per cent for regular workers and 1.7 per cent for irregular workers in the 2000s, and the number of formal strikes also decreased (Y-K. Lee, 2018: 37). Organised labour has faced a problem as irregular workers become a larger share of the Korean workforce - now constituting about 40 per cent of all Korean workers (McGrath, 2019). Increasingly, worker suicides in the 2000s have occurred among irregular workers in isolated homes, and few of them have been connected to broader labour campaigns in the way they commonly were before democratisation in 1987 (W. Kim et al., 2019). As the fractured labour community becomes increasingly informalised, 
and faces crippling legal strategies to destroy labour solidarity, we have witnessed a burst of individualistic worker suicides, as shown in the case of SsangYong workers and their families who have increasingly turned to isolated and individual acts of anomic suicide.

\section{From Anomie to Yeolsa: The Social Construction of Korean Worker Suicide}

Although current worker suicides are more often characterised as individualised and anomic rather than as heroic suicides by martyred yeolsas, even these anomic suicides retain the potential to inspire the collective actions of others and to leverage social change. The steady drumbeat of SsangYong worker suicides shows just this possibility. While union leaders struggled to leverage change at SsangYong in early stages of the labour conflict, very little changed at the company after the original spate of thirteen worker suicides in less than two years between 2009 and 2011. Between 2011 and the spring of 2018, seventeen more worker suicides followed the original burst of thirteen. Though worker suicides did not change dynamics on the ground, things changed in 2018 when the dramatic suicide of labour union leader Kim Ju-jung reignited the SsangYong issue in the public consciousness and inspired sympathy from the newly elected Korean president, Moon Jae-In. Kim Ju-jung had suffered from physical trauma due to police action during the labour strike in 2009, and he was one of the remaining 119 workers who were not fully reinstated after the company finally agreed to reinstate workers in 2015. Kim's retirement fund had been taken away by the company due to his involvement with the strike, since Korea's anti-union laws allow companies to charge unions and workers for economic damages caused by illegal labour actions. His death after ten years of struggle fuelled a burst of public attention and inspired a new urgency among labour leaders facing the company. One analysis stated that "the death of Kim Ju-jung illustrates the reality of frustration of workers who are forced to wait longer [for resinstatement]" (J-Y. Park, 2019). President Moon Jaein also weighed in on behalf of workers, urging SsangYong executives to reinstate all remaining workers by 2020 .

Kim's death (the thirtieth SsangYong worker suicide) empowered unions in their negotiations with the company's CEO, Arnand Mahindra. Facing mounting public pressure and presidential intervention, Mahindra sought to resolve the conflict and prevent further worker suicides by reinstating all 119 dismissed workers. As a result, 60 per cent of dismissed workers quickly returned to work, while the remaining dismissed workers were scheduled to return by the summer of 2019 . Many previous asset seizures and compensation claims against workers by SsangYong were vacated. Workers celebrated the reinstatement agreement by gathering in song, tears and laughter at a memorial site set up in front of Seoul's Deoksu Palace to recognise the contributions of the thirty SsangYong workers who had committed suicide in the previous decade. "We have passed through a long night to arrive here today", Korean Metal Workers Union official Kim Deuk-joong remarked, while celebrating suiciding workers as heroes in the struggle (Y-K. Lee, 2018).

Though it remains unclear if all remaining workers will be reinstated even by the end of 2020 (one year later than originally promised) (Ilabor, 20 December 2019), many have been reinstated and progress for SsangYong workers has been real and meaningful. For this reason, the decade of SsangYong worker suicides fits within a tradition of socially meaningful suicides in Korea, even if many suiciding workers did not advance this perspective themselves. Many SsangYong suiciding workers died in despair and without hope that things would change for their families, but a decade of such individualised suicides ultimately did provoke broader public sympathy, favourable governmental intervention and positive changes for workers. 


\section{Conclusion}

While some workers commit suicide calling for great social and political causes, other commit suicide in more isolated fashion, expressing anomic helplessness and demoralisation to their loved ones. In Korea, worker suicides in the 2000s have shown increasingly anomic characteristics, which has been influenced by the unfolding of a neo-liberal Korean political-economic order characterised by the rise of contingent and exploitive jobs. At the same time, political-legal policies have been used to control labour through brutal mechanisms such as compensation suits, damage claims and provisional seizures. In a nation with a long tradition of yeolsa suicides for social purpose, it is understandable that current workers also commit suicide in response to these challenges though these suicides are increasingly isolated from broader labour actions, especially compared to past eras of Korean labour activism. Though these suicides may be products of personal anomie for the workers who commit them, the bedrock of socially meaningful worker suicide laid down most memorably by Chun Tae-il continues to resonate as the social meaning of these suicides is constructed by the broader Korean public. Even anomic worker suicide retains the capacity to spark the fire of broader social outrage as in Korea's past, and today's lonely yeolsas may still be charting paths towards collective action and labour militancy in the current neo-liberal economy.

\section{REFERENCES}

Biggs, M. (2005) Dying without Killing: Self-immolations, 1963-2002. In Making Sense of Suicide Missions, edited by G. Gambetta. Oxford: Oxford University Press.

Cheikh, I., C. Rousseau and A. Mekki-Berrada. (2011) Suicide as Protest against Social Suffering in the Arab World. The British Journal of Psychiatry, 198(6): 494-495.

Cho, K-B. (2015) Industrial Action and Liability in Korea. International Union Rights, 22: (1): 6-7.

Choi, J-J. (2010). The Democratic State Engulfing Civil Society: The Ironies of Korean Democracy. Korean Studies, 34: 1-24.

Choi, Y-R. (2003) A Single Spark: The Biography of Chun Tae-il. Seoul: Dolbegae Publishers.

Cook, T. (2003) Thousands of Workers in South Korea Strike against Repressive Labour Laws. World Socialist Web Site, November 19. https://www.wsws.org/en/articles/2003/11/kore-n19.html (accessed 2 July 2019).

Doucette, J. (2013) Minjung Tactics in a Post-Minjung Era? The Survival of Self-immolation and Traumatic Forms of Labour Protest in South Korea. In New Forms and Expressions of Conflict at Work, edited by G. Gall. London: Palgrave Macmillan.

Doucette, J. and S. Kang (2018) Legal Geographies of Labour and Post-democracy: Reinforcing Nonstandard Work in South Korea. Transactions of the Institute of British Geographers, 43(2): 200-214.

Durkheim, E. (2002 [1897]) Suicide: A Study in Sociology. London: Routledge.

Hart-Landsberg, M., R. Westra and S. Jeong (eds.) (2007) Marxist Perspectives on South Korea in the Global Economy. London: Routledge.

Heo, W. (2014) Four Reasons that Ssangyong Workers Cried. Huffington Post, November 13. http://www.huffingtonpost.kr/2014/11/13/story_n_6150786.html (accessed 15 March 2020).

HT Correspondent (2011) Mahindra Completes SsangYong Acquisition. Hindustan Times, March 15. https://www.hindustantimes.com/business/mahindra-completes-ssangyong-acquisition/storywpukH56HzjylFI6ojG3JKK.html (accessed 24 September 2020). 
International Trade Union Confederation (ITUC) (2012) Internationally Recognized Core Labour Standards in Republic of Korea. Report for the W'TO general council review of the trade policies of Republic of Korea, Geneva, 19 and 21 September. https://www.ituc-csi.org/IMG/pdf/korea_tpr_final.pdf (accessed 1 November 2018).

International Trade Union Confederation (ITUC) (2016) Update on Core Labour Standards in South Korea. https://www.epsu.org/sites/default/files/article/files/Update\%20on\%20Core\%20Labour\%20Standa rds\%20in\%20South\%20Korea\%20-\%20Oct\%202016.pdf (accessed 15 May 2018).

Ilabor (2019) The Compensation Suit against Ssangyong Workers is the State Violence. Ilabor.Org, December 20. http://www.ilabor.org/news/articleView.html?idxno=7415 (accessed 2 March 2020).

Jang, S-H. (2004a) Continuing Suicide among Labourers in Korea. Labor History, 45(3): 271-297.

Jang, S-H. (2004b) Korean Labor: Protest by Suicide. https://www.solidarity-us.org/node/406 (accessed 7 May 2017).

Kang, S-D. (2018) Democracy without Workers: The "Work Society" in Korea after Democratization. In The Quality of Democracy in Korea: Three Decades after Democratization, edited by H. Mosler, E-J. Lee and HJ. Kim. London: Palgrave Macmillan.

Korea Confederation of Trade Unions (KCTU) (2009) The Current Situation of Labor Rights in South Korea. 29 October 2018. [PDF supplied to the author by the KCTU.]

Kim, E-J. (2014) There was the Government behind the Provisional Compensation Suits of 169.1 Million Dollars. Sisain, March 6. https://www.sisain.co.kr/?mod=news\&act=articleView\&idxno=19584 (accessed 1 July 2019).

Kim, H-J. (2008) Micromobilization and Suicide Protest in South Korea, 1970-2004. Social Research, 75(2): 543-578.

Kim, M-J (2015) Six Years after Layoffs, Ssangyong Workers Keep Passing Away. Hankyoreh Newspaper, June 29. http://english.hani.co.kr/arti/english_edition/e national/689678.html (accessed 24 September 2020).

Kim, S-C. (2019) The Trajectory of Protest Suicide in South Korea, 1970-2015. Online only. Journal of Contemporary Asia, DOI: 10.1080/00472336.2019.1607889

Kim, W., M. Ki, M. Choi and A. Song (2019) Comparable Risk of Suicidal Ideation between Workers at Precarious Employment and Unemployment: Data from the Korean Welfare Panel Study, 2012-2017. International Journal of Environmental Research and Public Health, 16(2811): 1-20.

Koo, H. (1999) Modernity in South Korea: An Alternative Narrative. Thesis Eleven, 57(1): 53-64.

Koo, H. (2001) Korean Workers: The Culture and Politics of Class Formation. Ithaca, NY: Cornell University Press.

Korea Joongang Daily (2003) A Labor Tragedy (editorial). January 16. http://koreajoongangdaily.joins.com Lnews/article/Article.aspx?aid=1920271 (accessed 25 March 2019).

Kwon, D-S. (2015) Focus: Damage Claims and Provisional Seizure as a Means of Union Busting. International Union Rights, 22(1): 8-9.

Lee, B-H. (2015) Changing Cross-Movement Coalition Between Labor Unions and Civil Society Organizations in South Korea. Development and Society, 44(2): 199-218.

Lee, C-G. (2011) Do Words to Comfort these Children Exist in this World? Continuing Killing of Ssangyong Workers. Workers' Solidarity, 21(51): n.p. https://wspaper.org/article/9335 (accessed 10 March 2020).

Lee, C-W. (2005) Labor and Management Relations in Large Enterprises in Korea: Exploring the Puzzle of Confrontational Enterprise-based Industrial Relations. Visiting Fellow Working Paper. https://pdfs.semanticscholar.org/d5b5/24cc781086fadcd9d91f47f0133502160f3e.pdf (accessed 30 May 2016).

Lee, S-H. (2006) The Analysis of Provisional Law and Compensation Suit and the Limitation of Law (Korean). Center for Labor Policy, 6(3): 159-184. 
Lee, H. and G. Elich (2015) Union-led Popular Protests Push to Oust South Korean President. Labor Notes, December 8. http://labornotes.org/2015/12/union-led-popular-protests-push-oust-south-koreanpresident (accessed 7 July 2018).

Lee, N. (2007). The Making of Minjung: Democracy and the Politics of Representation in South Korea. Ithaca, NY: Cornell University Press.

Lee, S-G. (2004) Research About Illegal Strike, Compensation Suits and Provisional Sei₹ure. Seoul: Yangjungsa.

Lee, Y-J. (2017) The End of Gangjung Maeul? There are Seven more Retaliation Cases under the Lee Myung-bak Gyun-hae Government. Hankyoreh Newspaper, December 13. http://www.hani.co.kr/arti Lsociety/labor/823337.html (accessed 3 April 2019).

Lee, Y-K. (2015) Sky Protest: New Forms of Labour Resistance in Neo-liberal Korea. Journal of Contemporary Asia, 45(3): 443-464.

Lee, Y-K. (2018) Labor Politics and the Limits of Democracy in Korea. Taiwan Journal of Democracy, 14(2): $31-49$.

Lee, Y-K. (2019) Neo-liberal Methods of Labour Repression: Privatized Violence and Dispossessive Litigation in Korea. Journal of Contemporary Asia, (online only) 1-18. DOI: $\underline{10.1080 / 00472336.2019 .1663552}$

Lim, M-A. (2018) Yeolsa Bunnowa Seulpeumeu Junchibak [Martys: Politics and Anger and Sadness]. Seoul: Owoleubom.

McGrath, B. (2019) South Korean Public Sector Workers Strike Over Irregular Employment Status. World Socialist Web Site, 4 July. https://www.wsws.org/en/articles/2019/07/04/skor-j04.html (accessed 24 September 2020).

Nam, H-S. (2013) Progressives and Labor under Park Chung Hee: A Forgotten Alliance in 1960s South Korea. The Journal of Asian Studies, 72(4): 873-892.

Oak, Y-J. (2017) Report on Compensation Suit: The Current Trends and Issues about Workers' Provisional Seizure. Sonjabgo, June 28. http://www.sonjabgo.org/node/840 (accessed 2 June 2019).

Park, B-C. (1994) Political Suicide among Korean Youth. Bulletin of Concerned Asian Scholars, 26(1-2): 66-82.

Park, H-J. and H-W. Rho. (2015) The Path was Finally Open for the Reinstatement of Ssangyong Workers after Six Years of LayOffs. Hangyurae Nenspaper (December 30). http://www.hani.co.kr/arti/society/labor/724146.html (accessed April 3 2019).

Park, J-Y. (2019) The Major Outcome of Survey on Workers Who are Subject to Compensation Lawsuits, Infringement of Labor Rights, and the State of Health. In No Money to be Paid Off, No Colleagues Who Can't Return. First Public Representation about 236 Survey Result on Victim Workers due to the Compensation Suit. http://www.sonjabgo.org/sites/default/files/190124balpyohoejaryojib_gapeul_su_eobsneun_don_d olaoji_anhneun_dongryo_-sonbaegaabryu_pihaenodongja_ceos_siltaejosa_gyeolgwabalpyo.pdf (accessed 4 April 2020).

Park, R-G. (2017) Provisional Seizure and Compensation Suit for Labor Unions. How Long? Hankyoreh Newspaper, June 29. http://www.hani.co.kr/arti/opinion/column/800830.html (accessed 20 May 2018).

Song, H-Y. (2013) Democracy against Labour: The Dialectic of Democratisation and De-democratisation in Korea. Journal of Contemporary Asia, 43(2): 338-362.

Sun, M-S. (2019). Severance Pay from a Decade Ago Received after Reinstatement but Trapped in Despair due to Compensation Claims and Provisional Attachments. The Kyunghyang Shinmun, February 25.

Vijayenthiran, V. (2020) Mahindra facing Coronavirus Related Sales Plunge, Pulls Investment in SsangYong. Motor Authority, April 7. https://www.motorauthority.com/news/1025736_mahindra-facingcoronavirus-related-sales-plunge-pulls-investment-in-Ssangyong (accessed 7 April 2020).

Yi, J-B. (2019) Ssangyong Motor Workers Reinstated but still face State Lawsuits. Hankyoreh, June 25. http://english.hani.co.kr/arti/english_edition/e_national/899276.html (accessed 8 June 2020).

Waters, S. (2015) Suicide as Protest in the French Workplace. Modern \& Contemporary France, 23(4): 491-510. 


\section{BIOGRAPHICAL NOTE}

Minsun Ji is the outgoing director of the Center for New Directions in Politics and Public Policy at the University of Colorado Denver. She is a CU Denver lecturer on Labor Studies and Korean Political Economy. She is a research fellow at the New School of Social Science, and a J. Robert Beyster Employee Ownership Fellow with Rutgers University, School of Management and Labor Relations. [Email: minsunji@yahoo.com] 